\title{
EPS合成遮断壁による地盤振動遮断効果と その評価法の提案
}

\author{
早川 清1 ・ 中谷 郁夫 2 - 緒方 広泰 3 - 前 育弘 4 \\ 1フェロー会員 立命館大学教授＼cjkstart理工学部環境システム工学科（テ525-8577 草津市野路東 1-1-1） \\ kiyoshi@se.ritsumei.ac.jp \\ 2正会員 立命館大学大学院 総合理工学研究科（率525-8577草津市野路東1-1-1） \\ gr046051@se.ritsumei.ac.jp \\ 3積水化成品工業株式会社 総合研究所（干632-8505 奈良県天理市森本町670） \\ Ogata01@sekisuiplastics.co.jp \\ 4積水化成品工業株式会社（干163-0727 東京都新宿区西新宿2-7-1） \\ Mae01@sekisuiplastics.co.jp
}

\begin{abstract}
本論文では, 地盤振動問題における伝播経路対策に関して, 新たな地中振動遮断壁の遮断効果について 検討している．すなわち，EPS(Expanded Poly Styrene)とコンクリートとの合成遮断壁について，実物大の 合成遮断壁を実フィールドに埋設した。車両走行などで発生する振動を想定した加振実験を実施して，こ の合成遮断壁による振動低減効果を評価した. その結果, 3Hz付近の低域の卓越振動数において, 遮断壁 背面からの距離 $4.5 \mathrm{~m} \sim 10.5 \mathrm{~m}$ に着目すると平均で $4.5 \mathrm{~dB}$ 程度の低減効果を確認した。これらの検討より, 合 成遮断壁による振動低減効果の推定法として簡便な方法を考案して実験值と比較したところ, 本評価法に より実験值の定量的な推定が可能であることが判明した.
\end{abstract}

Key Words : EPS, composite wall, vibration isolation, measuremen, wave propagation

\section{1. はじめに}

公共輸送機関である鉄道車両の軌道走行や自動車の高 速道路や高架道路橋の走行，建設現場の建設機械，工場 の大型機械などによって生じる地盤振動は，周辺住民お よび作業者への環境問題を引き起こす場合がある. 公共 輸送機関の振動問題に着目すると, その発生場所のほと んどが都市部である。したがって，土地利用の高過密化 や渋滞緩和対策として高架橋形式による鉄道網や道路網 が輻輳して建設整備されてきたことも，振動問題の発生 の要因であると言える. こうした問題を環境保全の観点 から解決するために, 幾つかの対策方法が調查研究され ている.このような地盤振動対策には，発生源・伝播経 路・受振部におけるものがあり，伝播経路対策のうちの 地中振動遮断壁に着目すると，剛性壁であるコンクリー 卜, 鋼矢板, PC パイル, 空隙壁であるガスクッション

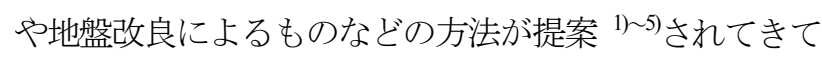
いる．しかしながら，EPS とコンクリートの合成遮断壁 でオーガー掘削による施工可能なものは見られない. 振
動低減効果が最も期待できる方法は, 構造物の建設時の 発生源における対策であると考えられるが，その効果を 定量的に見積もることは困難と思われるために, 建設当 初から振動対策を行うことは少ない.このような現状か ら, 苦情などの問題が発生してから対策が検討されるケ 一スが多い，著者等はこのような状況を踏まえて，交通 機関などの供用を阻害することなく対策が可能な伝播経 路対策の中から, 地中振動遮断壁について幾つかの材料 を用いた方法を研究している.

地中振動遮断壁は, 使用条件によっては大きな効果が 得られるために, 既往の研究報告 の 10)でも検討されてき ている. この場合の遮断壁材料には, 例えば, 鋼矢板や コンクリート，および地盤改良材などの，地盤に対して 波動インピーダンス（波動速度×密度）の大きい剛な材 料や発泡スチロールや発泡ウレタンなど波動インピーダ ンスの小さい軟らかい材料などが考えられている.

本論文では, 地中振動遮断壁として EPS 単体では浮 き上がりの問題があり, またコンクリート単体では施工 に手間がかかることに着目して, 写真 -1 亿示寸 EPS 


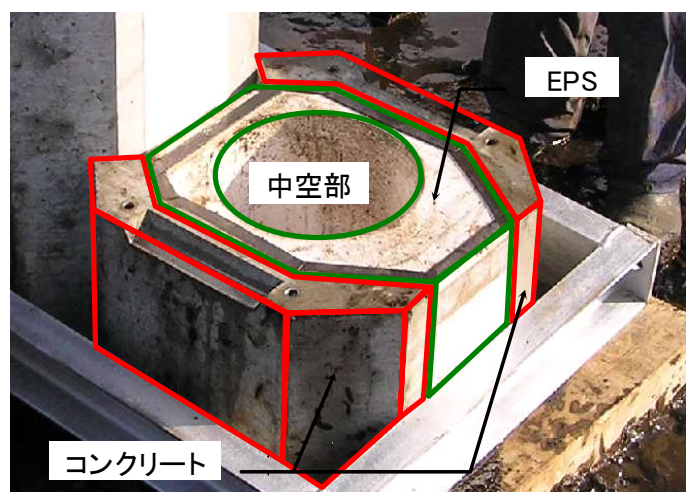

写真 - 1 合成遮断壁の形状

( Expanded Poly Styrene )とコンクリートの複合材料からな る新たな地中振動遮断壁の効果を検討するために，第 1 の中規模なフィールド実験と第 2 の実物大フィールド実 験を実施した．EPS とコンクリートの合成振動遮断壁 （以下，合成遮断壁）は，中心部に EPS を外側にコン クリートを配置したサンドイッチ構造で, 波動インピー ダンス比が大きいものと小さいものからなる複合材料で ある．第 2 の実験では実際の環境問題での遮断効果を評 価するために，実物大の合成遮断壁を軟弱地盤に埋設し て行い，加振条件を車両の段差走行などで発生する衝撃 的な振動を想定して, 重錘落下による実験法を採用した. その結果から, 地表面における距離と振動低減効果の関 係を確認した。 また，既往の研究では地表部の計測のみ を対象とする事例が多いが，本研究においては地中部に おける合成遮断壁の前後での深さ別の振動低減傾向も観 測した.さらに，中空部に EPS を充填した場合と中空 とした場合での低減効果も確認している. 最後に, 合成 遮断壁による振動低減効果に関して，波動の反射，透過， 回折現象をモデル化した簡便な推定法を提案した.

\section{2. 中規模フィールド実験}

実物大の合成遮断壁の振動低減効果を事前に確認する ために，中規模フィールド実験を行った，その振動低減 効果は，コンクリートと EPS の波動インピーダンスの 相違により発揮することが推察されるが, 現時点では, 芦谷等によるコンクリート壁体での振動低減効果の評価 手法 ${ }^{11)}$ は提案されているが，合成遮断壁の効果や予測法 は十分に確立されていないと考えられる。そこで本実験 により効果を確認するものである，実験では，実物と同 様な合成遮断壁材料と地盤材料を用いて，一つの小さな 実物としての縮尺を検討した。一般的にモデル実験など では，縮尺が小さいほど精度が低くなることが予測され るために, 本研究では学内フィールドで実験が行える可 能な範囲での最大縮尺である実物の $1 / 3$ 縮尺モデルの合 成遮断壁とした．また，実験場の地盤状況は，掘削状況

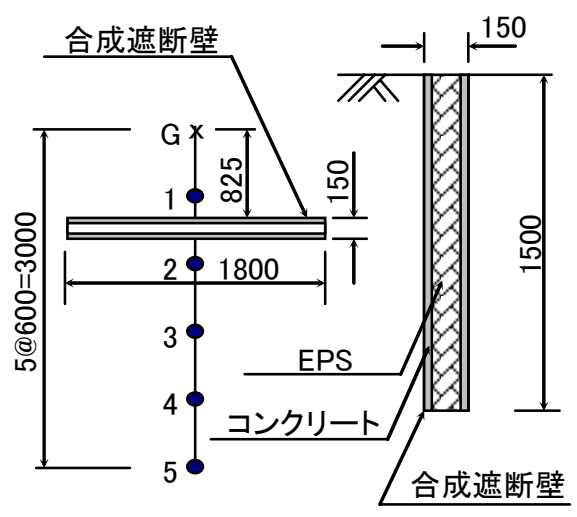

図 - 1 計測測点の配置及び断面

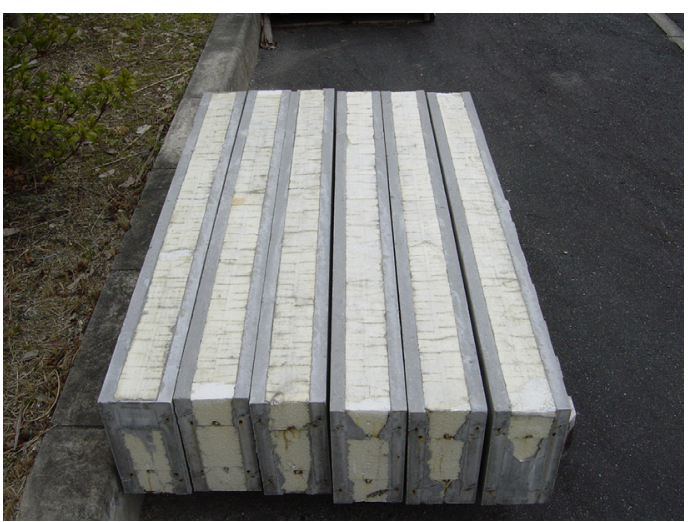

写真 - 2 中規模フィールド実験用の合成遮断壁

から表層面から GL-0.5m は砂碟で構成され, それ以深 では粘土である，表層からの採取試料より求めた湿潤密 度は $1.95 \mathrm{~g} / \mathrm{cm}^{3}$, 乾燥密度は $1.57 \mathrm{~g} / \mathrm{cm}^{3}$, 原位置試験より求 めた $\mathrm{S}$ 波速度は $149 \mathrm{~m} / \mathrm{s}$ であった。

\section{（1）合成遮断壁の想定と試験体}

実験用の試験体に関して，第 1 の実験では同材料のコ ンクリート (厚さ $3 \mathrm{~cm} \times 2)$ と $\mathrm{EPS}($ 厚さ $9 \mathrm{~cm}$ )を用いて，実 物の $1 / 3$ 縮尺モデルとなるように厚さ $15 \mathrm{~cm} \times$ 長さ $1.5 \mathrm{~m}$ の 形状とした，図 - 1 は，第 1 実験用の合成遮断壁の平面 配置および地中埋設状況を示したもので，写真 - 2 は使 用した合成遮断壁の状況である，その合成方法は，両端 のコンクリート版を EPS を貫通した異形鉄筋で結合し ている。両材料の密度および $\mathrm{S}$ 波速度は，EPS では密 度: $0.02 \mathrm{t} / \mathrm{m}^{3}, \mathrm{~S}$ 波速度: $340 \mathrm{~m} / \mathrm{s}$, コンクリートでは密 度: $2.4 \mathrm{t} / \mathrm{m}^{3}, \mathrm{~S}$ 波速度: $1900 \mathrm{~m} / \mathrm{s}$ である. 遮断壁の配置は幅 $1.8 \mathrm{~m} \times$ 厚さ $0.15 \mathrm{~m} \times$ 深さ $1.5 \mathrm{~m}$ として, 一枚当たりの寸法 : 幅 $0.3 \mathrm{~m} \times$ 厚さ $0.15 \mathrm{~m} \times$ 長さ $1.5 \mathrm{~m}$ の試験体 6 枚を地中で突 き合わせて地中に埋設した.

\section{(2) 加振入力}

第 1 の中規模フィールド実験における加振入力条件を 設定するために，第 2 の実物大フィールド実験場におい て，ポータブル型の振動測定装置（（株）東京測振製 


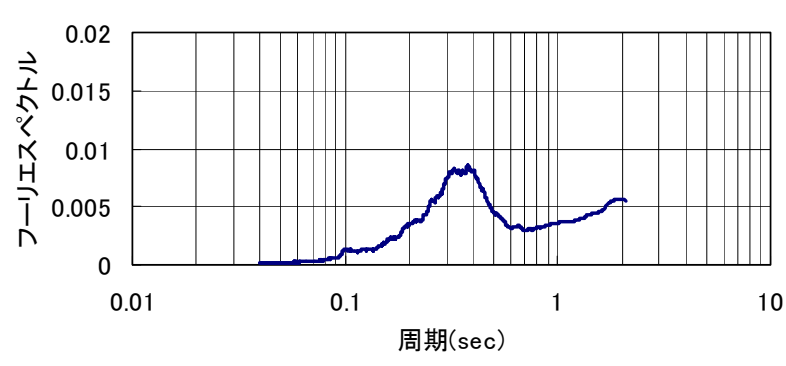

図 - 2 常時微動のフーリエスペクトル図 (UD成分)

SPC-35F）を用いて地盤の振動特性を把握するための常 時微動を測定 ${ }^{12}$ した. UD（上下成分）の測定結果から, 図 - 2 に示す上下方向のフーリエスペクトルから卓越振 動数は $2.5 \mathrm{~Hz} \sim 3 \mathrm{~Hz}$ 付近にあることを確認した。 そのた めに，第 1 の中規模なフィールド実験の入力振動数の目 標值を $2.5 \mathrm{~Hz} \sim 3 \mathrm{~Hz}$ 付近の低振動数として, 既存の最も 低い振動数を発生することができる不平衡マス型起振機 を用いて $10 \mathrm{~Hz}$ 付近の加振入力とした。

\section{（3）波動の観測}

本実験では，図 - 1 に示す地表面での振動の低減挙動 を観測した. 計測ラインを合成遮断壁の中心として加振 源から $3.0 \mathrm{~m}$ に設定し， $60 \mathrm{~cm}$ 間隔の 5 測点とした. そし て，不平衡マス型起振機を使用して $10 \mathrm{~Hz}$ 付近の振動数 域の振動を入力した. この時の地表面の応答振動レベル

（VL）の鉛直成分（Z 方向）を計測するために，5台の ポータブル振動計 (リオン(株)製 VM-52)を使用して各測 点の最大值を同時観測した.

\section{(4) 実験結果}

図 - 3 は, 約 $10 \mathrm{~Hz}$ 付近の入力振動数で入力した時の 地表面における自然地盤と合成遮断壁設置後の振動レベ ルの低減挙動を示したもので，加振点からの距離による 低減挙動を示している。

合成遮断壁の低減効果は，自然地盤での振動減衰挙動 と比較して，合成遮断壁の背面直後の加振点から $1.2 \mathrm{~m}$ 地点で $8 \mathrm{~dB}$ 程度, $1.8 \mathrm{~m}$ 地点で $7 \mathrm{~dB}$ 程度の効果が確認で きる. また，実物の 1/3 縮尺モデルの中規模フィールド 実験と実物大フィールド実験おける振動低減効果の比較 検証については，6章において考察している.

\section{3. 実物大フィールド実験}

千葉県千葉市内の約 $30.0 \mathrm{~m} \times$ 約 $25.0 \mathrm{~m}$ のフィールドに, 写真 - 3 に示すような中空部を有する EPS とコンクリー トの合成遮断壁を埋設した. 合成遮断壁 1 本当たりの形 状寸法を図 - 4 に示す. 幅 $0.40 \mathrm{~m} \times$ 厚み $0.435 \mathrm{~m} \times$ 長さ $1.5 \mathrm{~m}$

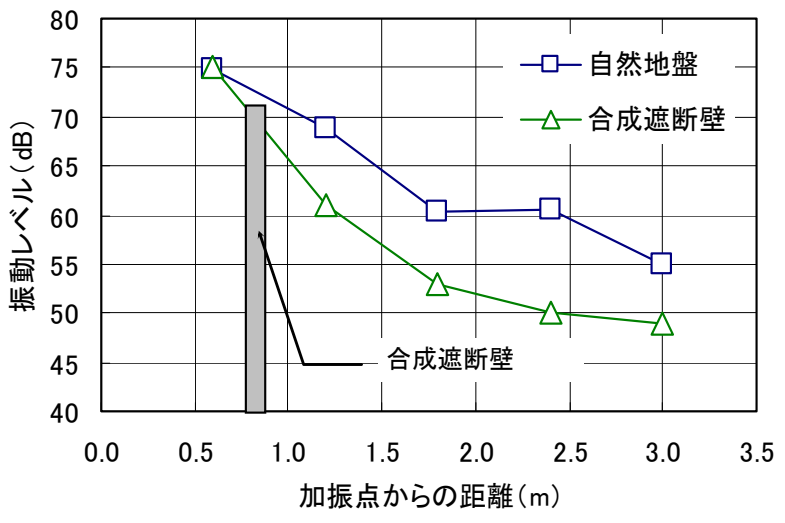

図 - 3 振動低減挙動の比較

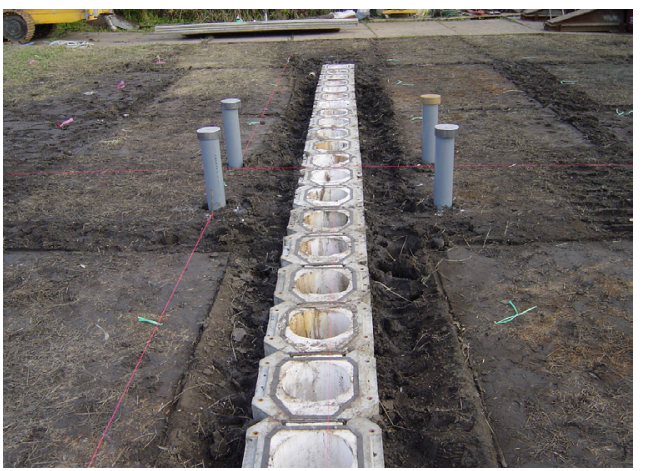

写真 - 3 合成遮断壁の埋設状況

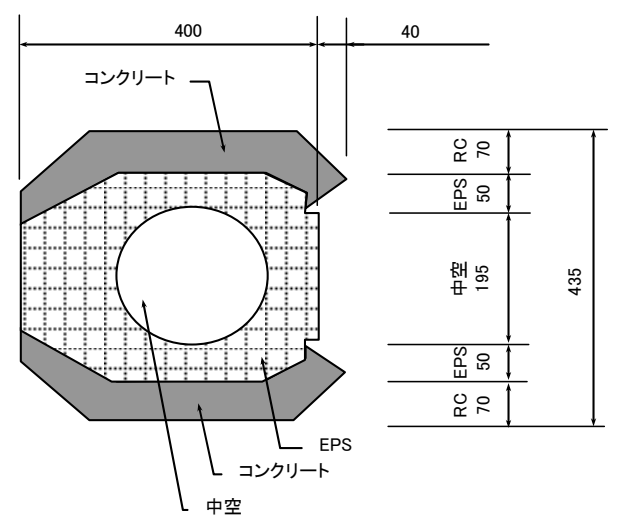

図 - 4 合成遮断壁の断面図

で, 外側にコンクリート $(7 \mathrm{~cm} \times 2)$ ，内側に EPS $(5 \mathrm{~cm} \times 2)$ と中空部（ $\phi 195 \mathrm{~mm})$ を有する構造である. 打込み延長および埋設深さは $L=10.0 \mathrm{~m} （ 25 \times 0.4 \mathrm{~m}=10 \mathrm{~m})$ ， $D=\mathrm{GL}-4.5 \mathrm{~m} \quad(3 \times 1.5 \mathrm{~m}=4.5 \mathrm{~m})$ で，延長方向の接合は突合 せにより行っており，打込み深さ方向はピース間をフラ ットバーとボルトを用いて接合している.

計測は，衝撃加振である重錘による自由落下法で行い， 地表面における合成遮断壁前後の振動低減傾向を把握し た．また，地中での波動伝播を確認するために，地中振 動計を用いて地盤内部での波動の動きを計測した.

図 - 5は，地表面での計測平面配置を示したものであ る. AからGの7測線を設定し, 1測線当たり11点の計77測 点を配置した。計測領域には，縦幅 $12.0 \mathrm{~m} \times$ 横幅 $21.435 \mathrm{~m}$ 
の区域を設定し，各 $2.0 \mathrm{~m} \times 2.0 \mathrm{~m}$ のメッシュの交点での振 動計測を行った. 加振点は, 図に示寸様に合成遮断壁の 中心Dライン上と, 端部Gライン上としている. 地中に おける加速度計測は, 合成遮断壁の前後の深さ $\mathrm{GL}-$ $2.5 \mathrm{~m}$ と $\mathrm{GL}-4.5 \mathrm{~m}$ の合計4測点に配置した．地表面の計測 では，ポータブル振動計(リオン(株)製VM-52)を使用し て振動レベル（VL）の上下成分（Z方向）を計測して, 合成遮断壁の有無による加振源からの距離ごとの振動值 を収録している，地中の計測では，地中に埋め込んだ塩 化ビニル管の中に地中振動計(東京測振 (株) 製SA-358)を 配置し，加速度アンプ(東京測振(株)製PC-217)を介した 計測システム (リオン(株)製SA-01A4) で加速度波形デー タを記録している．さらに遮断壁の裏面での計測結果の 検討より, 合成遮断壁による振動低減効果を確認した.

本実験では，振動の低減挙動の評価に振動レベルを採 用している. 振動レベルは振動規制に用いる振動量 ${ }^{13)}$ で, 必ずしも物理量そのものが人の感覚評価に最適というわ けではない観点から，振動感覚に対応寸る周波数補正を した量である. 振動レベルは, 次式で求められる.

$$
L v=20 \log \frac{a}{a_{0}}
$$

$$
\begin{array}{cl}
\text { ここに, } & \\
L v & : \text { 振動レベル }(\mathrm{dB}) \\
a_{0} & : \text { 基準の振動加速度值 }\left(10^{-5} \mathrm{~m} / \mathrm{s}^{2}\right) \\
a & :\left(\sum a_{n}^{2} \cdot 10^{C n / 10}\right){ }^{1 / 2} \\
a_{n} & : \text { 周波数 } n(\mathrm{~Hz}) \text { における振動加速度実効值 }(\mathrm{dB}) \\
c_{n} & : \text { 周波数 } n(\mathrm{~Hz}) \text { におけるる補正值 }(\mathrm{dB})
\end{array}
$$

\section{4. 実物大フィールド実験の結果と考察}

実験大フィールドの地盤状況は，ボーリング調査より 表層面から GL- $8.0 \mathrm{~m}$ は, 粘土およびシルトで構成され， $\mathrm{N}$ 值が 1 程度である．室内試験結果によると，土粒子密 度が $2.82 \mathrm{~g} / \mathrm{cm}^{3}$ であり, 強熱減量試験の結果が $91.89 \%$ で あることから，有機質土と推測される，それ以深は N 值 10 程度の砂質土であり, 軟弱な地盤である. 図 - 6 にボーリング柱状図を示す.

振動入力は重錘で行い，その形状寸法は，先端が平ら な円柱形で $\phi 35 \mathrm{~cm} \times$ 高さ $46.3 \mathrm{~cm}$ の質量 $350 \mathrm{~kg}$ の鋼製で, 高さ $1.0 \mathrm{~m}$ から自由落下して行っている. 実験回数は, 地表面において振動計 5 台を同時に使用して, 遮断壁中 心ライン上の振動入力では, 77 測点を 1 ケースあたり 3 回実施して, 遮断壁端部ライン上の振動入力では, 55 測点を 1 ケースあたり 3 回実施している.また，地中で は 1 台の加速度計で 4 測点の計測を 3 回実施した。 測定 ケースは，遮断壁を中空とした場合と中空部を充填した 場合の計測と, 遮断壁端部からの振動入力では中空部充

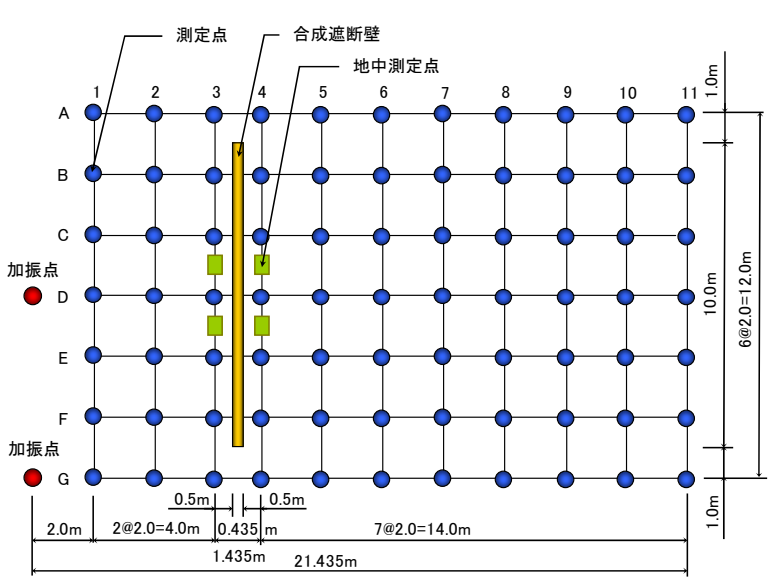

図 - 5 振動計測点の配置

土質区分值

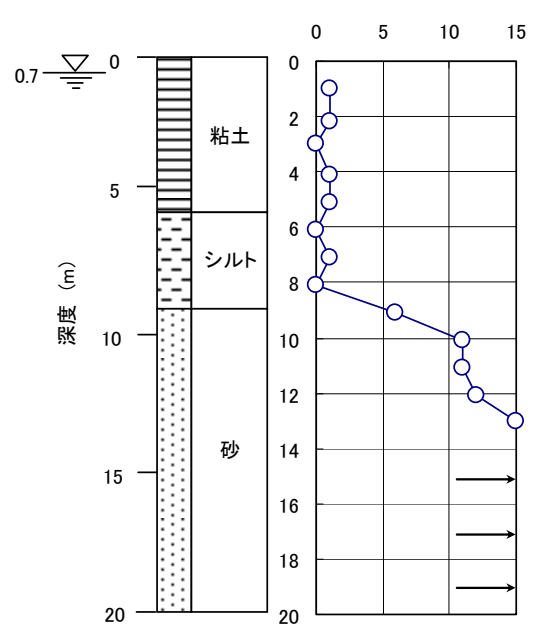

図 - 6 ボーリング柱状図

填のみとし，重錘を全 150 回程度落下させて実験を実施 した. 重鍾落下時に生じる加振点での凹みについては, 落下毎に地盤を均一に敷き均しながら実施した。 また, 繰り返しの重鍾落下により地盤が締め固められて入力条 件がばらつくことが懸念されたが，今回の実験では，重 錘落下毎に加振点付近でデータのばらつきを計測したが 地表面が極めて軟弱地盤であるためにばらつきはそれほ ど現れないことを確かめている.

D ラインの合成遮断壁前後における地盤の応答卓越振 動数を, FFT 分析装置を用いて求めた振動加速度の $1 / 3$ オクターブ分析結果の一例を図 - 7 に示寸.これより, $3.15 \mathrm{~Hz}$ 付近が卓越しており, 低い振動数の波動が発生し ていることが分かる.

\section{（1）地表面の振動低減挙動}

図 - 8に示すグラフは，重錘落下時の自然地盤での振 動低減挙動と, 合成遮断壁埋設後の挙動を比較して表し たものである.これらの比較データは，鉛直方向の振動 レベル（VL）の計測代表值であり，壁の中心線であるD ラインでの状況である. これより, 自然地盤に比べて遮 


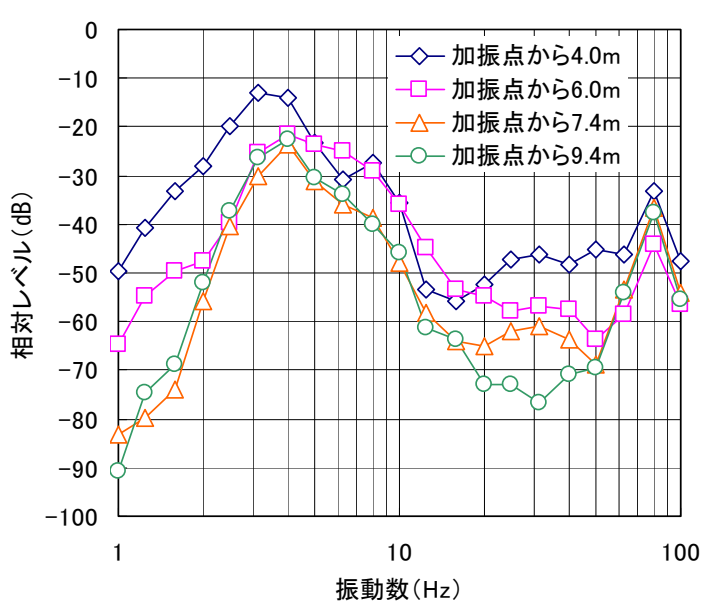

図 - 7 1/3 オクターブ分析による結果

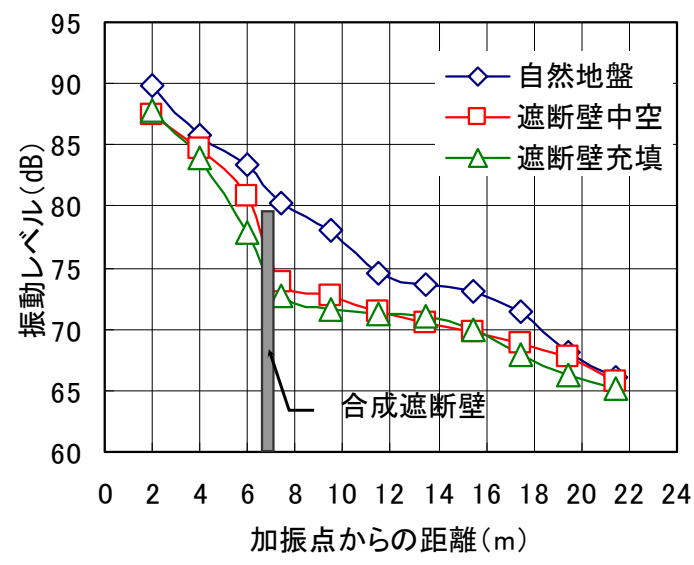

図 - 8 振動低減挙動の比較

断壁の背面から $4.5 \mathrm{~m}$ の地点までは約 $6 \mathrm{~dB}$ 程度の振動低減 量を示し, その後 $10.5 \mathrm{~m} ま て ゙ は 3 \mathrm{~dB}$ 程度の振動低減量を示 している．壁の背後 $10.5 \mathrm{~m}$ 付近までは大きな振動低減傾 向を示しているが，12.5m付近では自然地盤とほぼ同じ 值を示している．これは, 合成遮断壁の底部および端部 からの回折波動による影響と考えられる.この回折波動 の影響については，4章(4)節で検証している.

\section{（2）中空部充填による振動低減への影響}

写真 - 1 に示寸合成遮断壁を中空とした測定は，施工 時の中堀工法の機能を果たすとともに, 既往の地中遮断 壁の研究 ${ }^{14)}$ から空溝の遮断効果が最も大きいことを考慮 したものである.このことから，中空部は空の方がより 性能が発揮されると推定される。 しかしながら，実際の 現場では地下水などの浸入により中空を保つことは困難 である. そのために写真 - 4 に示寸合成遮断壁の中間層 と同じ材料である円柱形の EPS 充填材を，特に接着剤 を使用せずに挿入した場合の振動低減挙動についても観 測を行った. その結果も図 - 8 に示している. 振動の低 減挙動は，中空時に比べて充填材料を入れた場合のケー スでは， $1 \mathrm{~dB}$ 程度の振動低減効果の増加傾向のあること

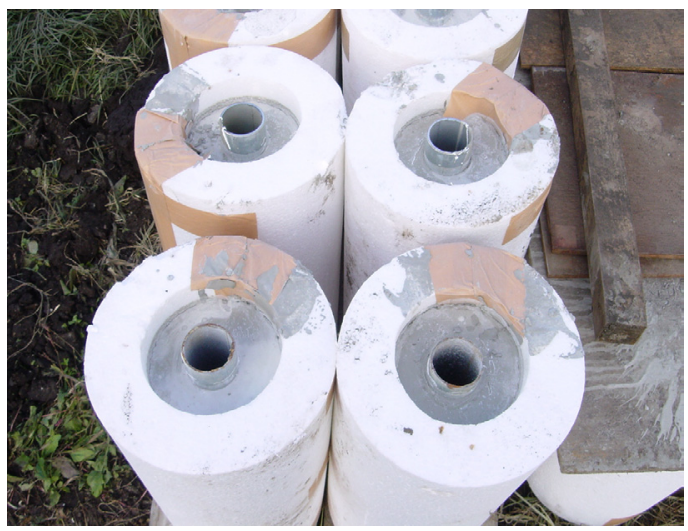

写真 - 4 充填材の形状

が分かったこれは，今回の振動実験においても中空 部に地下水が浸入しており，実際には中空部に水を充 填した場合と EPS 充填材を挿入した場合の振動低減効 果を比較したものとなっている。一般に地中に固体また は液体の境界面を設けた場合の波動伝播は，固体と固体 の境界では $\mathrm{P}$ 波および $\mathrm{S}$ 波が伝達し，固体と液体の境界 では P波のみが伝達することが知られている ${ }^{15)}$. したが って，充填材を挿入した場合は，P波と $\mathrm{S}$ 波の影響によ り振動低減効果が充填前と比較して小さくなることが予 測された. しかし，今回の実験では振動低減量が大きく なっており。これは，充填部の EPS とコンクリートの インピーダンスの相違が波動の透過量を減少に寄与した ものと考えられる.

\section{（3）合成遮断壁の埋設深さによる振動低減効果}

図 - 9 に示すグラフは，合成遮断壁の背面の加振点か ら 7.4m 9.4m 地点について, 遮断壁の埋込み深さ $(H)$ を波長（入）で除して無次元化した数值で示したもので ある. 重錘落下とショベル走行の実験を行ったので， $R$ は複数值を求めている，そこで，自然地盤と対策後地盤 との加速度振幅比 $\left(A / A_{0}\right)$ を求めて両者の関係を示した ものである.これは，波動の波長と合成遮断壁の埋め込 み深さの関係の振動低減効果への相関性を示したもので, 合成遮断壁の実測值と空溝の実験值を示したものである. 両者は地盤条件が異なるので, 埋め込み深さを波長で除 して無次元化して比較した.

空溝実験による加速度振幅比は, 次式で表現されてい る $^{14)}$.

$$
\gamma=\exp (-2.35 R)
$$

ここに,

$\gamma:$ 加速度振幅比

$R: H / \lambda$, 溝の深さと波長との比 


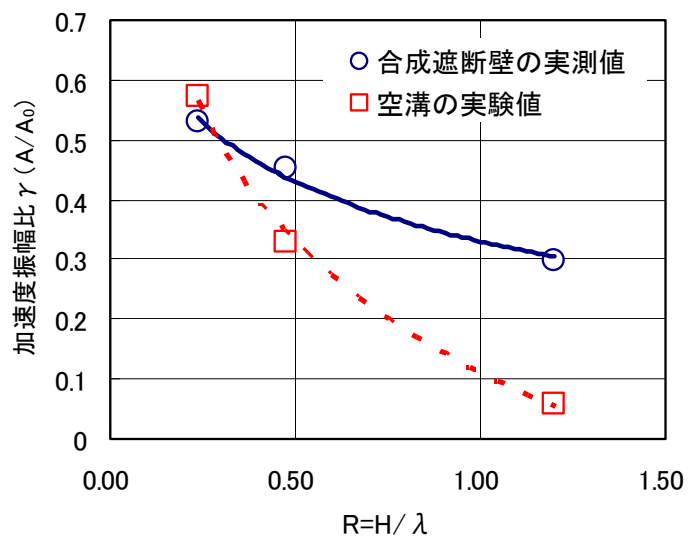

図 - 9 加速度振幅比と $R$ の関係

ここで，表面波の伝播速度を別途計測した弾性波探 查から算定し, 振動数で除した值から波長を推定してい る. 既往の研究から, 遮断壁の打設深さを波長に対比し た場合の効果 ${ }^{10,17}$ は，一般的に $1 / 2$ 波長以下では効果が 現れないが $1 / 2$ 波長以上になると効果が現れ，1 波長以 上でさらに効果が増加するといわれている，今回の実験 では, 合成遮断壁の実測值は $1 / 4$ 波長で $\gamma=0.55$ 程度の 振幅比を示し, $1 / 2$ 波長では $\gamma=0.45$ 程度であり, その 後 1 波長以上では, $\gamma=0.3$ を示している. 空溝の実験 值 ${ }^{14)}$ と比較すると, 波長に対して埋込深さの浅い $1 / 4$ 波 長程度においては空溝と同様な振幅比を示寸．その後は 波長に対して埋込み深さが深くなるにつれて，空溝ほど 振幅比が低減しないことが分かった。

\section{（4）合成遮断壁端部からの波動の回折}

図 - 10 に示すコンター図は，地表面における合成遮 断壁端部から回折した波動の振動レベルの最大值での伝 播状況を示している. 加振点は合成遮断壁端部の測線 $\mathrm{G}$ ラインと Fラインの中点延長線上で行っている. この目 的は，合成遮断壁の設置前および設置後の地表面の上下 方向の振動レベルを同時観測して，回折状況を確認する ためである. このときの $R=H / \lambda$ (溝の深さと波長の比 の関係）は，0.24程度である.

コンター図の振動レベル分布の様相から，Woods らの 研究成果 ${ }^{15)}$ からも知られるように回折の影響の無い範 囲は，加振点と合成遮断壁の端部を結ぶ線の端点を中心 とした $\theta=20$ 程度の位置にある境界線と, 合成遮断壁の 裹側を結ぶ範囲にあることが分かった．図には Woods らが行った受動的振動絶縁試験 ${ }^{15}$ における， $R=H / \lambda$ が 1.19 とした場合の回折の影響範囲 $\theta=25^{\circ}$ も示している. この結果は, 今回の実験とほぼ同様な傾向を示している ことが分かる. また，図示していないが，E ラインの観 測からも回折影響が現れる測定点は, 加振点から $15.44 \mathrm{~m}$ 以降である.これは, 図 - 8 に示した自然地盤と 合成遮断壁埋設後の効果の比較において, 加振点から
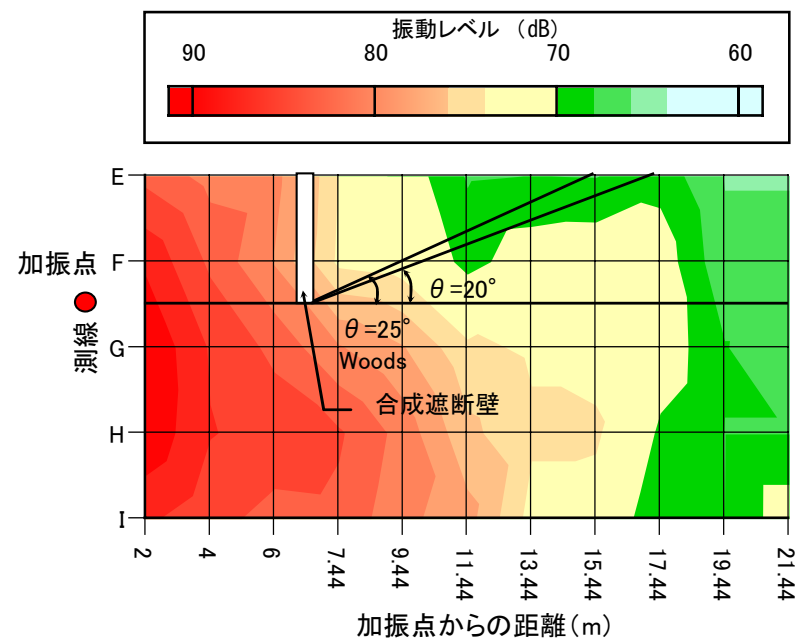

図 - 10 振動レベルのコンター図

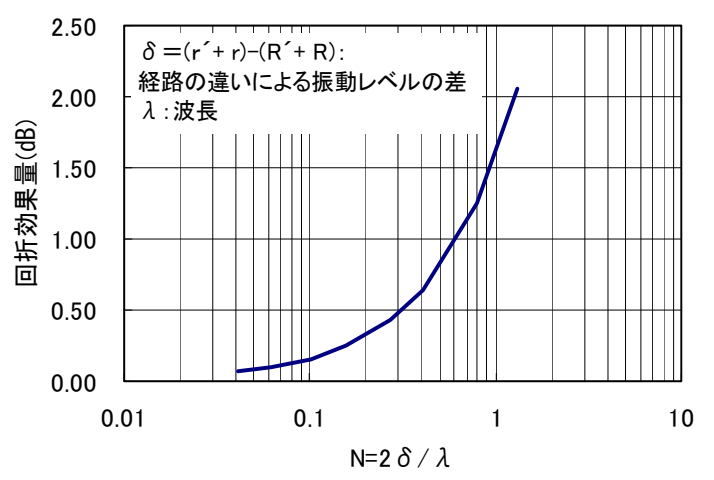

図 - 11 合成遮断壁の回折効果

$20.0 \mathrm{~m}$ 以降では低減効果に大きな差が無くなっているこ とを示唆している.

図 - 11 は，合成遮断壁による回折効果 ${ }^{18)}$ を調べたも のである，横軸は，遮断壁に直角方向に進む波動と遮断 壁の端部から回折する波動の経路差を波長で除した值で, 遮断壁裏側の加振点から $7.4 \mathrm{~m} \sim 21.4 \mathrm{~m}$ 地点の值に相当し ており, 縦軸は回折効果量である, このグラフでの $N=1$ 付近は，遮断壁の裏面に最も近い地点を表現しており， 回折の影響を $1.5 \mathrm{~dB}$ 程度受けていることが分かる.また， $N=0.1$ 付近は遮断壁から最も離れた地点に相当し, 回折 の影響を $0.1 \mathrm{~dB}$ 程度受けるだけである.これらの事項は, 上述したコンター図による回折傾向の考察と符合してい ると思われる。

経路差の概念を図 - 12 に示寸. また，その計算式は 次式で表現される ${ }^{18)}$.

$$
\delta=\left(r^{\prime}+r\right)-\left(R^{\prime}+R\right)
$$

ここに,

$\delta \quad:$ 経路の違いによる振動レベルの差 $(\mathrm{dB})$

$r{ }^{\prime} \quad$ : A 点と $\mathrm{C}$ 点の振動レベルのパワー和 $(\mathrm{dB})$

$r \quad: \mathrm{D}$ 点と $\mathrm{E}$ 点の振動レベルのパワー和 $(\mathrm{dB})$

$R^{\prime}$ : $\mathrm{A}$ 点と $\mathrm{B}$ 点の振動レベルのパワー和 $(\mathrm{dB})$

$R \quad: \mathrm{B}$ 点と $\mathrm{E}$ 点の振動レベルのパワー和 $(\mathrm{dB})$ 


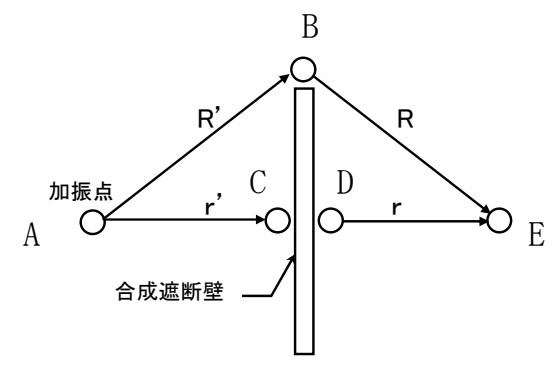

図 - 12 経路差の概念図

\section{（5）地中の振動低減挙動}

中心ライン上の合成遮断壁から約 $50 \mathrm{~cm}$ の距離の前面 と背面の 4 箇所にボーリング孔を掘削し, 深さ $2.5 \mathrm{~m}$ と $4.5 \mathrm{~m}$ 地点に振動計を配置した. 図 - 2 の常時微動のフー リエスペクトル困からも卓越周期を確認しているが，こ の観測による鉛直成分の加速度応答波形の一例を図 - 13 に示す。これは, 衝撃加振による応答波形である。この 波形からも, 主要な発生振動数が $3 \mathrm{~Hz}$ 程度であること が確認できる．また，波形が正弦波形状であることから も, 一定の振動数成分が卓越して発生していると考えら れる.

図 - 14 は，地表面から深さ $4.5 \mathrm{~m}$ までの地中について， 合成遮断壁中空部を充填した場合と中空（水が充填され た状態）での挙動を観測して示したものである．充填し たものに着目した合成遮断壁の裏面の深さごとによる振 動低減挙動は，地表面での振動加速度は深さ $2.5 \mathrm{~m}$ 地点 で $25 \%$ 程度低減されており，根入れ先端部である深さ $4.5 \mathrm{~m}$ 地点では振動低減量が小さく, 逆に少し増加する 傾向を示している. これは，深さ $4.5 \mathrm{~m}$ までは遮断壁に よる反射および透過現象のために振動低減効果を示すが, それ以深では低減効果が小さい。このことは，従来から の伝播経路対策の概念と符号している ${ }^{17)}$.

地中では加速度出力で計測しているので. 中空部の充 填効果を環境振動として評価するために, 加速度レベル 表示として比較したものを図-15 に示す. 遮断壁の前面 では，地表面で $2.9 \mathrm{~dB} ， \mathrm{GL}-2.5 \mathrm{~m}$ で $1.9 \mathrm{~dB} ， \mathrm{GL}-4.5 \mathrm{~m}$ で $5.9 \mathrm{~dB}$ の低減効果を示し, 最も深い地点で最大の効果を 示している.また，裏面では地表面で $1.1 \mathrm{~dB}, \mathrm{GL}-2.5 \mathrm{~m}$ で $4.0 \mathrm{~dB}$ の低減効果を示すが， GL-4.5m では $0.5 \mathrm{~dB}$ の増 加を示している. これは，地中部での波動の回折影響に よるものと考えられる. 背面では遮断壁前面に比較して 振動低減量が小さい傾向を示す。したがって，背面では 中空部の充填による波動の透過低減量が表現されている. これにより，地表面と同様に地中部の観測においても， 中空部を充填した場合の方が，中空部に何も充填しない 場合に比較して波動インピーダンスの相違による波動低 減効果が期待できるようである.

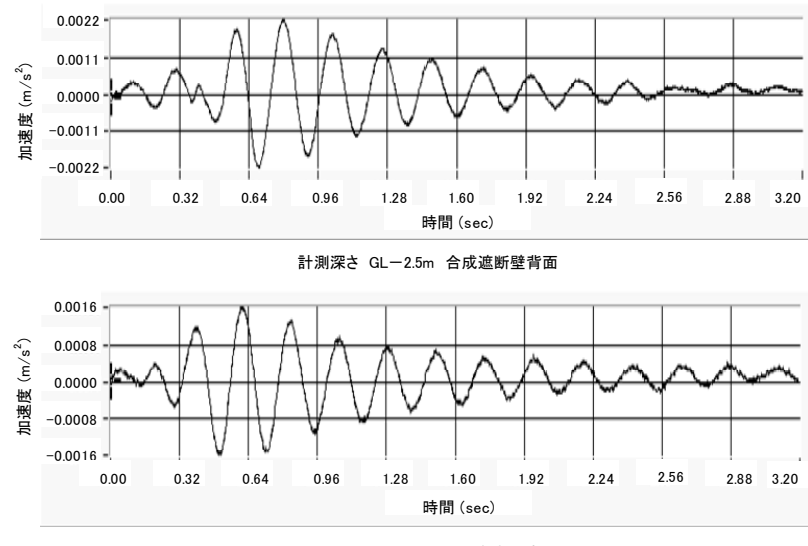

計測深さ GL $-4.5 \mathrm{~m}$ 合成遮断壁背面

図 - 13 地中の加速度波形

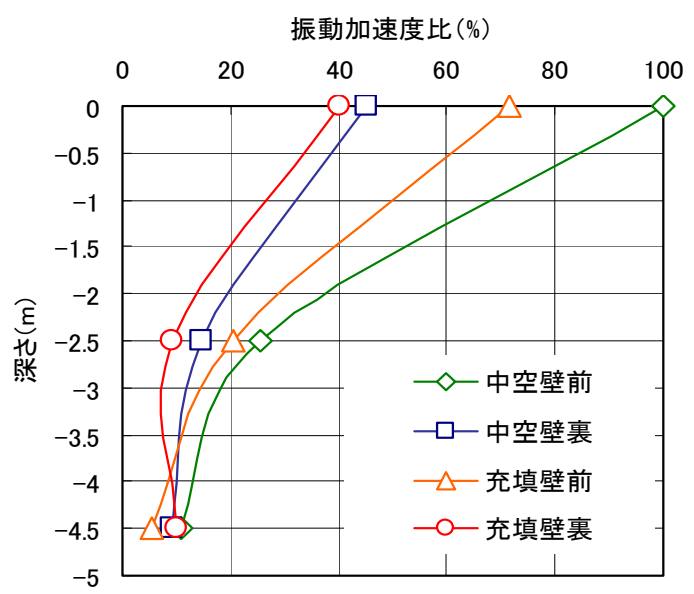

図 - 14 深さと加速度比との関係

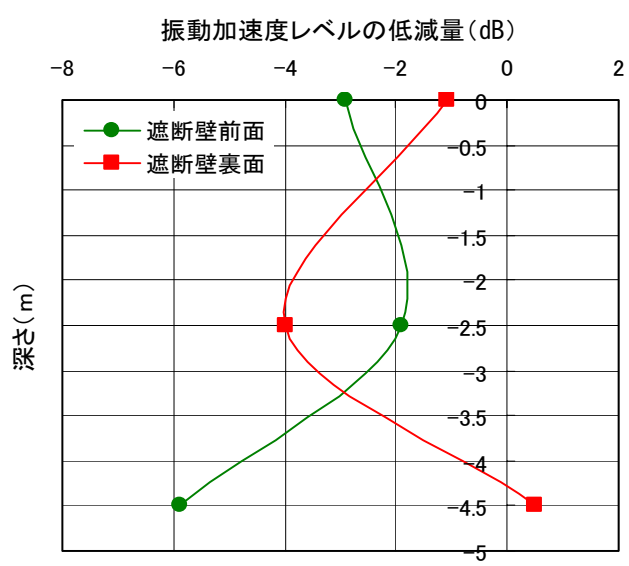

図 - 15 中空部の充填効果

\section{5. 合成遮断壁による振動低減効果の推定}

本研究で対象としているような，合成遮断壁の地表面 での振動低減効果を推定する方法は，まだ確立されてい ないと思われる. そのために，以下に示すような評価法 を提案し，実測結果と比較してその有効性を検討した。 


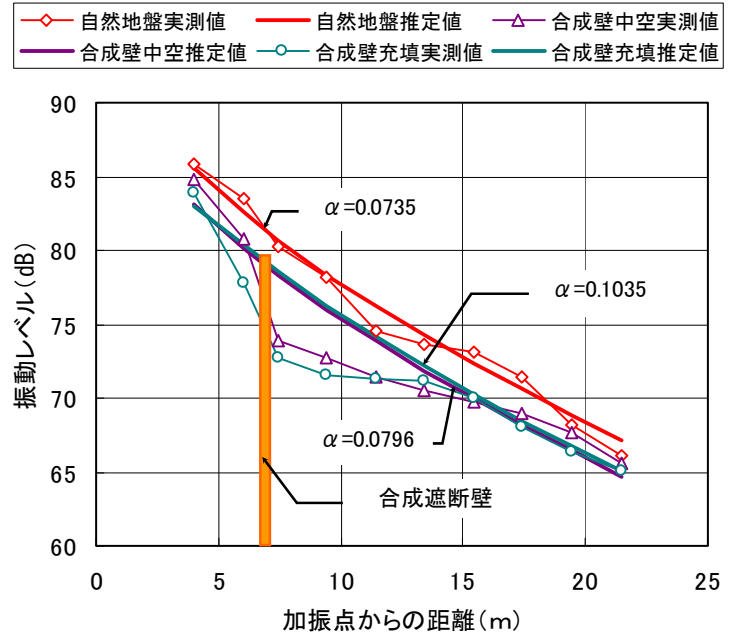

図 - 16 距離减衰の推定值と実測值

初めに表面波の距離减衰式を用いて幾何減衰および内部 減衰による低減量を求め, この值を波動インピーダンス 理論により壁の透過量を求めて補正した，その後に合成 遮断壁の端部からの回折波の効果を補正して振動低減効 果を推定する簡便な方法である. 幾何減衰および内部減 衰から距離减衰を推定する式は，次式で表される ${ }^{14)}$.

$$
L_{r}=L_{0}-8.7 \alpha\left(r-r_{0}\right)-20 \log \left(\frac{r}{r_{0}}\right)^{n}
$$

ここに,

$L_{r}$ : 加振点から $r(\mathrm{~m})$ 離れた地点の振動レベル $(\mathrm{dB})$

$L_{0}:$ 加振点から $r_{0}(\mathrm{~m})$ 離れた地点の振動レベル $(\mathrm{dB})$

$\alpha$ : 内部減衰を表す係数(推定值)

$n$ : 波の種類により定まる定数

ここでは，表面波に相当する $n=0.5$ とする

図 - 16 に推定值と実測值による比較を示す。自然地 盤および遮断壁から $15 \mathrm{~m}$ 以上の遠距離部では，推定值 で実測值が概ね表現されているが，遮断壁背面の部分で は表現されていないことが分かる，そのために，遮断壁 を無限長の壁と考えて推定值を波動透過理論で補正する. 波動透過理論による振動低減効果は，一般的に次式で表 現される ${ }^{18)}$ 。この場合の波動透過モデルを図 - 17 に示 す.

ここに,

$$
R=\frac{2 \beta}{\sqrt{\left(\beta^{2}-2\right)^{2} \sin ^{2} \frac{2 \pi}{\lambda} w+4 \beta^{2}}}
$$

$R$ ：地中振動遮断壁の右側媒質における変位振幅

$\beta\left(\rho_{n} V_{n} / \rho_{n}, V_{n}\right)$

: インピーダンス $\rho \cdot V$ (密度・ $\mathrm{S}$ 波速度)の比

$W$ : 壁体の厚さ $(\mathrm{m})$

$f$ : 振動数 $(\mathrm{Hz})$

$\lambda$ : 波長 $V / f$ (伝播速度 / 振動数 $)(\mathrm{m})$

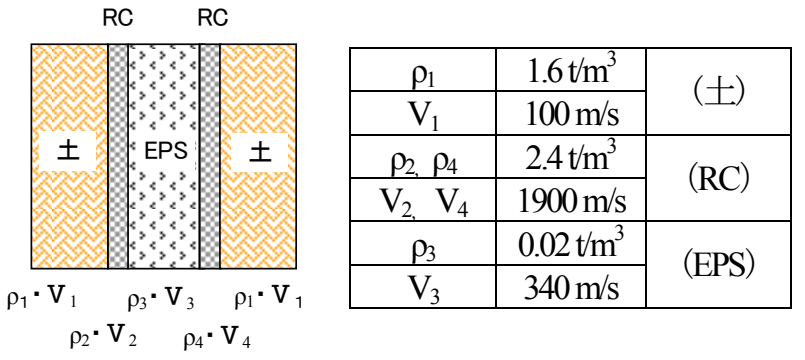

図 - 17 波動透過モデル

また，図 - 17 に示す土のせん断波速度は，図 - 6 のボ ーリング柱状図から $\mathrm{N}$ 值を 1 として今井他による推定 式（6）19）で求めた推定值としている.

$$
V_{S}=97.0 N^{0.314}
$$

ここに,

$V_{S}:$ せん断波速度 $(\mathrm{m} / \mathrm{s})$

$N$ : 地盤の $\mathrm{N}$ 值

ここで求めた結果を，さらに 4 章(4)節で示した経路差 による回折効果で修正するものとする.

図 - 16 に示した幾何減衰および内部減衰より推定し た值に対して，波動透過理論式（5）によってコンクリ 一トと EPS による波動の透過量を $\mathrm{dB}$ 換算して求めて補 正した．さらに，合成遮断壁を透過する波動と遮断壁端 部から回折する波動の経路差による低減量を式（3）で 求めて補正した。図 - 18 に示すグラフは，提案手法に よる推定值と実測值を比較したものである。このときの 波長と遮断壁深さの関係 $R=H / \lambda$ は, 図 - 9 から 0.24 に 相当するものとしている. 遮断壁前後の低減効果は, 実 測值に近似した值として再現されている.

推定值は，次式で表現される.

$$
R^{\prime}=L_{r}-R-\delta
$$

ここに,

$R^{\prime}$ ：推定值の振動レベル $(\mathrm{dB})$

$L_{r}$ : 加振点から $r(\mathrm{~m})$ 離れた地点の振動レベル $(\mathrm{dB})$

$R \quad$ : 遮断壁の振動低減効果量 $(\mathrm{dB})$

$\delta \quad ：$ 経路の違いによる振動レベルの差 $(\mathrm{dB})$

合成遮断壁の背面地点である加振点から $7.435 \mathrm{~m}$ 地点 に着目した推定值 $R$ の計算例を示す. 自然地盤の距離 減衰による推定值 $L_{r}$ は, 式(4)から $\alpha=0.00735, n=0.5$ と して求めると $80.5(\mathrm{~dB})$ となる. つぎに, 図-17 に示す波 動透過モデルの条件から式(5)において遮断壁の振動低 


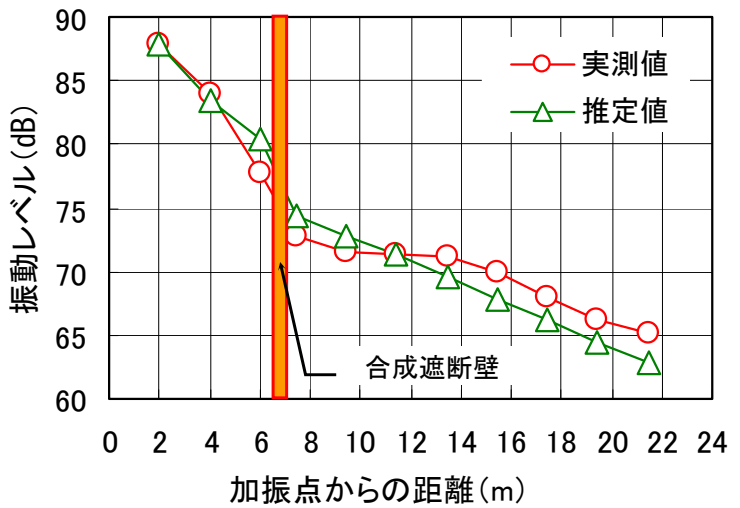

図 - 18 距離减衰の推定值と実測值

減効果量 $R$ を求めると $4.1(\mathrm{~dB})$ である. また，上記に示 した距離减衰式(4)から図-12 に示寸遮断壁端部 B 点, 遮断壁の前面 $\mathrm{C}$ 点および背面の $\mathrm{D}$ 点と $\mathrm{E}$ 点を求めて式 (3)から経路の違いによる振動レベルの差 $\delta$ を求めると $2.1(\mathrm{~dB})$ となり, 式(7)より $R^{\prime}$ は $74.3(\mathrm{~dB})$ となる.

したがって，本手法のような簡便な評価法においても 定量的な振動低減効果を推定できることが理解された.

\section{6. 中規模フィールド実験と実物大フィールド実 験の比較}

中規模フィールド実験と実物大フィールド実験での合 成遮断壁の振動低減効果を比較したものが図 - 19 であ る. 本図は, 遮断壁裏面からの距離と振動低減量との関 係を示したもので, 遮断壁裏面から $10.0 \mathrm{~m}$ 地点までに着 目して比較している.

中規模フィールド実験での振動低減量は，遮断壁裏面 の $0.5 \mathrm{~m}$ 付近で 7 $8 \mathrm{~dB}, 2.0 \mathrm{~m}$ 付近で $6 \mathrm{~dB}$ である. また, 実物大フィールド実験では $0.5 \mathrm{~m}$ 付近で $7.5 \mathrm{~dB}, 2.5 \mathrm{~m}$ 付近 で $6.5 \mathrm{~dB}$ の低減量を示し，その後 $3.0 \mathrm{~m}$ 以降では， $3.0 \mathrm{~dB}$ 程度の低減量を示寸, この結果からも, 両実験による振 動低減傾向は, 合成遮断壁の裏面付近ではほぼ同様な傾 向を示すことがわかる．したがって，回折の影響が少な い合成遮断壁の裏面では，両者の遮断効果は同程度にな ると考えられる.

また, 図 - 19 には, 既往の研究において実施された, 神田らの $\mathrm{PC}$ 柱列壁を用いた防振性能実験 ${ }^{20}$ における振 動低減量を比較して示している. このケースでの入力振 動数は, 合成遮断壁実験の条件に近い值である $10 \mathrm{~Hz}$ を 採用しており，壁の埋め込み長さを $6.0 \mathrm{~m}$, 内径 $0.62 \mathrm{~m}$ の 実物大の PC 柱列における振動低減量を示したものであ る. 遮断壁裏面の $5 \mathrm{~m} \sim 10 \mathrm{~m}$ の範囲での振動低減量は, $1 \mathrm{~dB}$ 程度である. また, 合成遮断壁との振動低減量との 差は, 平均して $3.0 \mathrm{~dB}$ 程度であることが分かる. この両 地中壁の構造の違いは，中間部がコンクリートか EPS かである.したがって, EPS とコンクリートの組み合わ

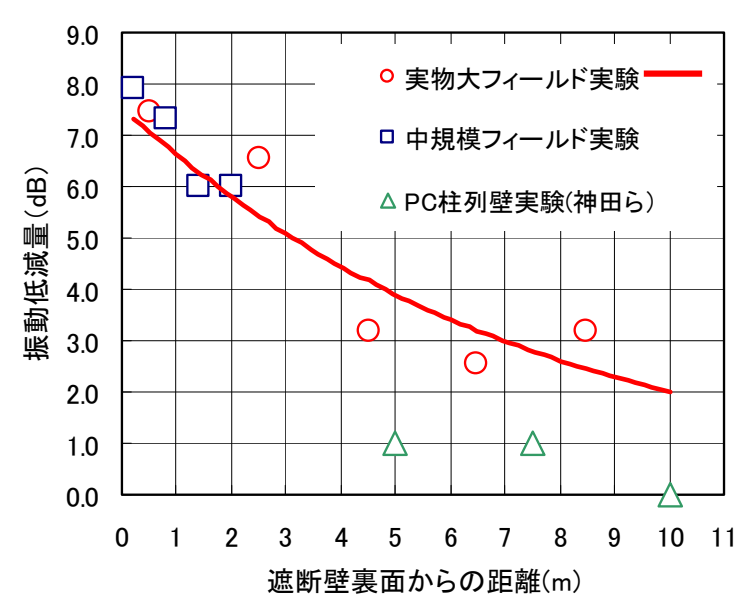

図 - 19 低減量の比較

せにより, 波動インピーダンスの差が大きくなり, 振動 低減効果が PC 柱列よりも大きく示されたものと考えら れる. ただし, 今後の定量的評価においては, 対象地盤 条件を考慮して検討寸る必要があると考えている.

\section{7. 結論}

本研究では，地盤振動の伝播経路対策工としての EPS 合成遮断壁の振動遮断特性を検討するために, 中規模フ ィールド実験および実物大フィールド実験を行い，その 遮断効果を検討した. さらに簡便な方法による遮断効果 の推定法を提案して, 実測值と比較して考察した.

本研究の範囲で得られた結果をまとめると, 以下の通 りである.

（1） 中規模フィールド実験においては，実物大の合成 遮断壁の $1 / 3$ 縮尺モデルに対応する入力振動数を $10 \mathrm{~Hz}$ 付近として, 振動の低減挙動を自然地盤と比 較した. その結果, 加振点から $1.2 \mathrm{~m}$ 地点 (遮断壁 裹面から $0.22 \mathrm{~m}$ ) で $8 \mathrm{~dB}$ 程度, $1.8 \mathrm{~m}$ 地点 (遮断壁 裏面から $0.82 \mathrm{~m})$ で $7 \mathrm{~dB}$ 程度の低減量を示した.

（2）実物大フィールドの地盤振動特性を把握するため に事前に常時微動を測定した結果, 卓越振動数が $3 \mathrm{~Hz} \sim 4 \mathrm{~Hz}$ であった. また, 現地実験での重錘自由 落下法による卓越振動数が $3.15 \mathrm{~Hz}$ 付近に現れたこ とから, 衝撃的な振動入力を行った場合, 地盤の 固有振動数に近い值の応答を示すことが知られた.

（3）実物大フィールド実験における合成遮断壁の振動 低減効果量は, 遮断壁裏面から $5 \mathrm{~m}$ 地点までは約 $6 \mathrm{~dB}$ 程度を示し, その後 $10 \mathrm{~m}$ までは $3 \mathrm{~dB}$ 程度の低 減量を示した。

（4）合成遮断壁の中空部への充填による振動低減効果 量に関し，水を充填した場合と円柱形の EPS 充填 材を挿入した場合の低減量の差は, 壁裹面の地表 面において後者の場合が $1 \mathrm{~dB}$ 程度の効果を示した. 
（5）合成遮断壁の打設深さと振動低減効果の関係は， $1 / 4$ 波長程度の深さにおいては空溝と同様な低減効 果が得られたが，1/2 波長以上の埋め込み深さでは 空溝ほどの低減効果を示さないことが分かった。

（6）地表面における波動低減挙動のコンタ一図から, 合成遮断壁の端部からの波動の回折影響を受けな い範囲は，加振点と合成遮断壁の端部を結ぶ線の 端点を中心とした $\theta=20^{\circ}$ 程度の位置にある境界線 と，合成遮断壁の裏側を結ぶ範囲にあることが分 かった.また，回折効果量を経路差から計算した值 からも，コンター図による回折傾向が説明できる.

（7）合成遮断壁の前後における地中振動計を使用した 観測で，地表面および遮断壁中間部における振動 低減効果を確認した。 また，遮断壁根入れ先端部 では振動低減効果の小さいことが分かった。また， 地中においても中空部への充填による振動低減効 果を確認した.

（8） 中規模フィールド実験と実物大フィールド実験に よる振動低減効果は，ほぼ同様な傾向を示すこと が分かり，遮断壁裏面における振動低減効果量は, 縮尺 $1 / 3$ のモデル実験において実物值に近い值を 示した.

（9）合成遮断壁の振動低減効果の評価法として，表面 波の距離減衰式から求まる值を，波動透過理論式 および経路差による回折式を用いて補正する簡便 な手法を考案した．本提案式による推定值と実験 による実測值とを比較した結果，提案式により実 測值の定量的な推定が可能であることが分かった.

\section{参考文献}

1) 財団法人鉄道総合技術研究所 : 環境省環境管理局請負調 査 新幹線鉄道振動対策手法検討調查報告書, pp.30, 2004 .

2) 吉岡 修, 石崎昭義 : 空溝・地中壁による地盤振動低減効 果に関する研究一東海道新幹線大草高架橋区間一, 鉄道 技術研究報告，No.1147（施設編第 502 号），pp.67， 1980 .

3) 早川 清 : PC 壁体による地盤振動対策工の設計・施工事例, 地盤環境振動の予測と対策に関するシンポジウム論文集, pp.100-104, 2004.
4) 櫛原信二，野津光夫，日置和昭 : ガスクッションを用い たハイブリット遮断壁の鋼矢板仕様に関する一考察，第 41 回地盤工学研究発表会, pp.2391-2392, 2006.

5) 橋本光則, 竹宮宏和, 白神敦秀 : WIB による構造物の振 動対策の事例，基礎工，pp.5457，2002.

6) Massarsch, K. R. : Vibration Isolation using Gas-Filled Cushions, Soil Dynamics Symposium to Honor Prof. Richard D. Woods, Geofrontiers 2005, Austin, Texas, January 24 26, 2005. Submitted for publication.

7) 早川 清, 神村洋介, 緒方広泰, 中谷郁夫 : 重錘落下実験 によるコンクリート・EPS 合成地中壁の振動実験, 土木学 会第 60 回年次学術講演会, pp.361-362, 2005.

8) 庄司正弘, 西村忠典 : 鉄道振動対策に関する数值シュミ レーション解析事例，土木学会関西支部共同研究グルー プ “鉄道振動の予測・防止に対する研究会” 報告書, pp.25-34, 2003.

9) 竹宮宏和, 島袋ホルヘ: 交通振動対策法「八ニカム $\mathrm{WIB} 」$ の減振効果一高架橋基礎周辺配置ケースー, 土木 学会論文集, No.108/I-74,pp.103-112, 2006.

10）早川清, 天野勲, 竹下貞雄: 発泡スチロールによる地盤 振動の低減効果に関する実験, 土と基礎，38-6（389）, pp.46-49, 1990.

11) 芦屋公稔 : 振動遮断工の防振効果の評価手法, 物理探査, 第 58 巻第 4 号, pp.351-362, 2005.

12）早川 清, 脇根教真, 鍋島康之, 太井子宏和 : 自動車振動 及び常時微動の測定による地盤の振動伝播特性, 地盤工 学会, 地盤環境振動の予測と対策に関するシンポジウム 論文集, pp.149-154， 2004.

13）経済産業省産業技術環境局 : 公害防止の技術と法規〔振 動編]，pp.48-49， 1996.

14）江島淳 : 地盤振動と対策, pp.201-209, 集文社, 1979.

15） Ricchart, F. E. Jr., Woods, R. D. and Hall, J. R. Jr. : 土と基礎の振動, pp.265-266, pp.278-284, 鹿島出版会, 1975.

16) 早川 清, 北村弘和, 畠山直隆 : 空溝による振動伝播の遮 断効果について, 立命館大学理工学研究所紀要, 第 41 号, pp.94-104, 1982.

17) 早川 清 : 地盤振動の伝播過程における防止対策の背景と 動向, 日本音響学会誌, 55 巻 6 号, pp.449-454, 1999.

18) 庄司 光, 山本剛夫, 畠山直隆 : 衛生工学ハンドブック騒 音・振動編, pp.441-445, 朝倉書店, 1980.

19）社団法人 地盤工学会 : 地盤·基礎構造物の耐震設計〔地盤 工学・実務シリーズ 13], pp.79-80, 2001.

20) 神田 仁, 石井啓稔, 吉岡 修, 平川康行, 川村淳一, 西村 忠典 : 起機実験および数值解析による PC 柱列壁の防振性 能, 物理探査, 第 58 巻第 4 号, pp.377-389, 2005.

(2006.6.13 受付) 


\title{
THE PROPOSAL ABOUT EFFECT ON A DECREASE IN THE GROUND VIBRATION OF THE COMPOSITION ISOLATION WALL OF CONCRETE AND EPS AND THE APPRAISAL METHOD
}

\author{
Kiyoshi HAYAKAWA, Ikuo NAKAYA, Hiroyasu OGATA and Yasuhiro MAE
}

The hollow composition isolation wall made of concrete and EPS (Expanded Poly Styrene) was investigated to reduce transmission of vibration. A full-scale experiment was conducted with the wall. The vibration was given by free falls of a weight to simulate vibration from construction works and vehicles. Aa for effect on a decrease in vibration, including embedded depth of the composition isolation wall showed the effect of $4.5 \mathrm{~dB}$ on the average even in about $1 / 4$ of the wavelength $3 \mathrm{~Hz}$ in the nearby low frequency number of vibration. And, it was found that the range where the diffraction from the end part of the isolation wall didn't affect was within $\theta=70^{\circ}$ behind the wall. Based on the results, a simple method to estimate the reduction of vibration by the composition wall was proposed. The proposed method estimated the vibration reduction well, and it was found that the method can be used to quantitatively estimate the efficiency of composition isolation wall. 